\title{
A taste for aliens: contribution of a novel prey item to native fishes' diet
}

\author{
Riikka Puntila-Dodd (1) - Olli Loisa · Katariina Riipinen • Amy E. Fowler
}

Received: 18 October 2018/Accepted: 26 May 2019/Published online: 29 May 2019

(C) The Author(s) 2019

\begin{abstract}
Non-indigenous species (NIS) can alter food web structure and function in many ways. While the predatory and competitive roles of NIS in aquatic environments are commonly studied, their role as a prey item for native predators is often overlooked. As the northern Baltic Sea lacks native crabs, the omnivorous estuarine Harris mud crab (Rhithropanopeus harrisii) is a novel invader to the system and provides an opportunity to observe how the species enters the prey field of predatory fish. In fall 2013, 1185 stomachs from 17 fish species were dissected and
\end{abstract}

R. Puntila-Dodd ( $\square)$

Marine Research Centre, Finnish Environment Institute, P.O. Box 140, 00251 Helsinki, Finland

e-mail: riikka.puntila-dodd@ymparisto.fi

R. Puntila-Dodd

Department of Aquatic Sciences, University of Helsinki, P.O. Box 65, 00014 Helsinki, Finland

O. Loisa

Faculty of Technology and Business, Turku University of Applied Sciences, Lemminkäisenkatu 30, 20520 Turku, Finland

K. Riipinen

Department of Biology, University of Turku,

20014 Turku, Finland

A. E. Fowler

Environmental Science and Policy Department, George Mason University, 4400 University Drive MS 5F2,

Fairfax, VA 22030, USA analyzed for the presence of $R$. harrisii. Fishermen had previously reported finding crabs mostly in the stomachs of perch (Perca fluviatilis), a frequent catch in recreational and commercial fisheries, but our study also found large numbers of crabs in four-horned sculpins (Myoxocephalus quadricornis) and small numbers in other species' stomachs (Rutilus rutilus, Leuciscus ide, Gymnocephalus cernuus, and Blicca bjoerkna). In the study area occupied by $R$. harrisii, four-horned sculpins were the most frequent predator, with $83 \%$ having at least one crab in their stomach. In comparison, 7\% of perch and roach had consumed $R$. harrisii. Most crabs eaten were 10-12 $\mathrm{mm}$ (carapace width), despite broader size range available (1-26 mm). Predation on $R$. harrisii in this system may be limited by the predators' gape size (i.e., physical feeding restriction). These results highlight the need to understand the role of novel invasive species as prey items for native species, ultimately increase understanding of whether native predators can control NIS populations.

Keywords Non-indigenous species $\cdot$ Novel invasion · Predation control · Food web - Baltic Sea · Rhithropanopeus harrisii 


\section{Introduction}

As the impacts of non-indigenous species (NIS) in aquatic environments have drawn increased attention in past years (Carlton and Geller 1993; Simberloff et al. 2013), many studies have concentrated on the top-down predatory impacts of an invader on native prey or their competitive interactions with both native and other introduced species. In reality all species, including NIS, have both predatory and prey roles in food webs, and nearly all NIS are eventually preyed upon by native predators, sometimes leading to reductions in NIS population sizes (Hunt and Yamada 2003; Jensen et al. 2007). One of the most notable marine examples comes from the Chesapeake Bay, USA, in which native blue crabs exert considerable predation pressure on the iconic invasive green crab to the point where there are no green crab populations in the Chesapeake (DeRivera et al. 2005). On the other hand, newly abundant prey items can increase a predators' fitness as shown with native fish predators and an invasive prey (round goby) in the Laurentian Great Lakes, USA (Crane et al. 2015). Sometimes the increased resource leads to an increase in predator populations and results in increased predation on native species as well (Noonburg and Byers 2005). In addition, prey naivety towards invasive predators has been widely studied and reported (e.g., Sih et al. 2010), but far less attention has been given to the naivety of predators, although similar naivety may occur especially towards novel prey (Ward et al. 2010), which may result in low predation pressure on the novel species.

The Harris mud crab, Rhithropanopeus harrisii (Gould 1841), invasion in the northern Baltic Sea presents an interesting opportunity to investigate how a novel prey item becomes part of native predators' diets. There are no native crab species in the area (Ojaveer et al. 2006), and therefore predators may be slow or even naive towards adopting this new prey into their diets. R. harrisii originates from the Atlantic coast of North America (from Canada to the Gulf of Mexico) and has successfully invaded over 20 countries, including those in Europe, Asia, Central America, and the west coast of North America, making it one of the most successful brachyuran crabs in the world (Roche and Torchin 2007). R. harrisii is an integral member of estuarine communities throughout its range, serving as a generalist predator of small biota, a prey species for numerous vertebrate and invertebrate predators, and a host for several parasite species, including Loxothylacus panopaei (Odum and Heald 1972; Williams 1984; Grosholz and Ruiz 1995).

The first observation of $R$. harrisii in the Baltic Sea was made in the 1930s in the Kiel Channel in Germany (Schubert 1936) and later in 1950 in Poland (Demel 1953). In the 2000s, $R$. harrisii began to spread northward, and it was recorded in Lithuania in 2000 (Bacevicius and Gasiunaite 2008), in Finland in the Archipelago Sea in 2009 (Fowler et al. 2013) and in Estonia in 2011 (Kotta and Ojaveer 2012). Since 2009, the range and abundance of $R$. harrisii in the Archipelago Sea has increased rapidly. Currently, the monitoring of $R$. harrisii in the area is largely based on public observations through the Finnish Alien Species Portal (www.vieraslajit.fi), which reports to the Finnish Biodiversity Information Facility database (FinBIF 2017), with locations and species identifications verified by scientists from the Finnish Environment Institute (SYKE) and the Natural Resources Institute (Luke).

The first confirmed public observations of $R$. harrisii in fish stomachs in the Archipelago Sea were received in 2011 (Fowler et al. 2013; FinBIF 2017). Since that time, the geographical range and abundance of reports of $R$. harrisii found in fish stomachs has increased along with the increased range of $R$. harrisii. Based on these public observations, $R$. harrisii are most frequently found in the digestive tracts of perch (Perca fluviatilis (Linnaeus 1758)) (around 10 observations yearly). P. fluviatilis is the most important catch in recreational fisheries (Luonnonvarakeskus 2014) and provides the fourth largest catch (in tonnes) commercially (RKTL 2013) in the study area. Because recreational catches are mainly composed of this single predator, public observations of $R$. harrisii in fish stomachs were likely effort-biased and unlikely to accurately reflect the diversity of predators consuming $R$. harrisii in the Archipelago Sea.

Aiming to investigate which fish species and the proportions of species that consume novel $R$. harrisii in their invasive range in the Archipelago Sea in Finland, we investigated the stomachs of nearly 1200 fish, representing 17 species of commercial and noncommercial significance in the fall of 2013. Furthermore, we aimed to assess the contribution of $R$. harrisii to stomach contents and infer whether 
predation was equally distributed across all size classes of $R$. harrisii available in the area.

\section{Methods}

Fishing and stomach content analyses

Sample collection was organized simultaneously with the Annual HELCOM Coastal Fish Monitoring effort in the Kaitvesi region. Fish were collected from both the official survey catch (Kaitvesi) and from nine other sites (altogether 10 sites) in the Archipelago Sea, SW Finland (Fig. 1) between September 9 and November 8,2013 . The southernmost location, Nötö, was outside the known range of $R$. harrisii, and since $R$. harrisii were detected neither from the fish stomachs nor from the habitat traps (see below), these data were excluded from further analyses. In Kaitvesi, 45 Nordic Coastal survey nets (multi mesh size 10-60 mm) were deployed according to HELCOM Coastal Fish Guidelines (HELCOM 2015). Additional fish from the other nine sites were collected with 5-15 bottom gillnets per site (30 m length, $1.5-3 \mathrm{~m}$ height, mesh size $30-80 \mathrm{~mm})$. All fish caught were collected and transported to the Turku University of Applied Sciences on ice. They were then measured (total length (TL), $\mathrm{mm}$ ) and weighed ( $\mathrm{g}$ ), and their digestive tracts were dissected out and carefully visually inspected for contents including $R$. harrisii remains. All identifiable $R$. harrisii were tallied, and individuals with intact carapaces were also measured (carapace width $(\mathrm{CW}), \mathrm{mm})$ using calipers. In addition, their contribution to the stomach contents was estimated as a proportion of all stomach contents. The number of nets and the overall sampling effort varied between locations, and therefore the data was pooled for the whole area for further analyses.

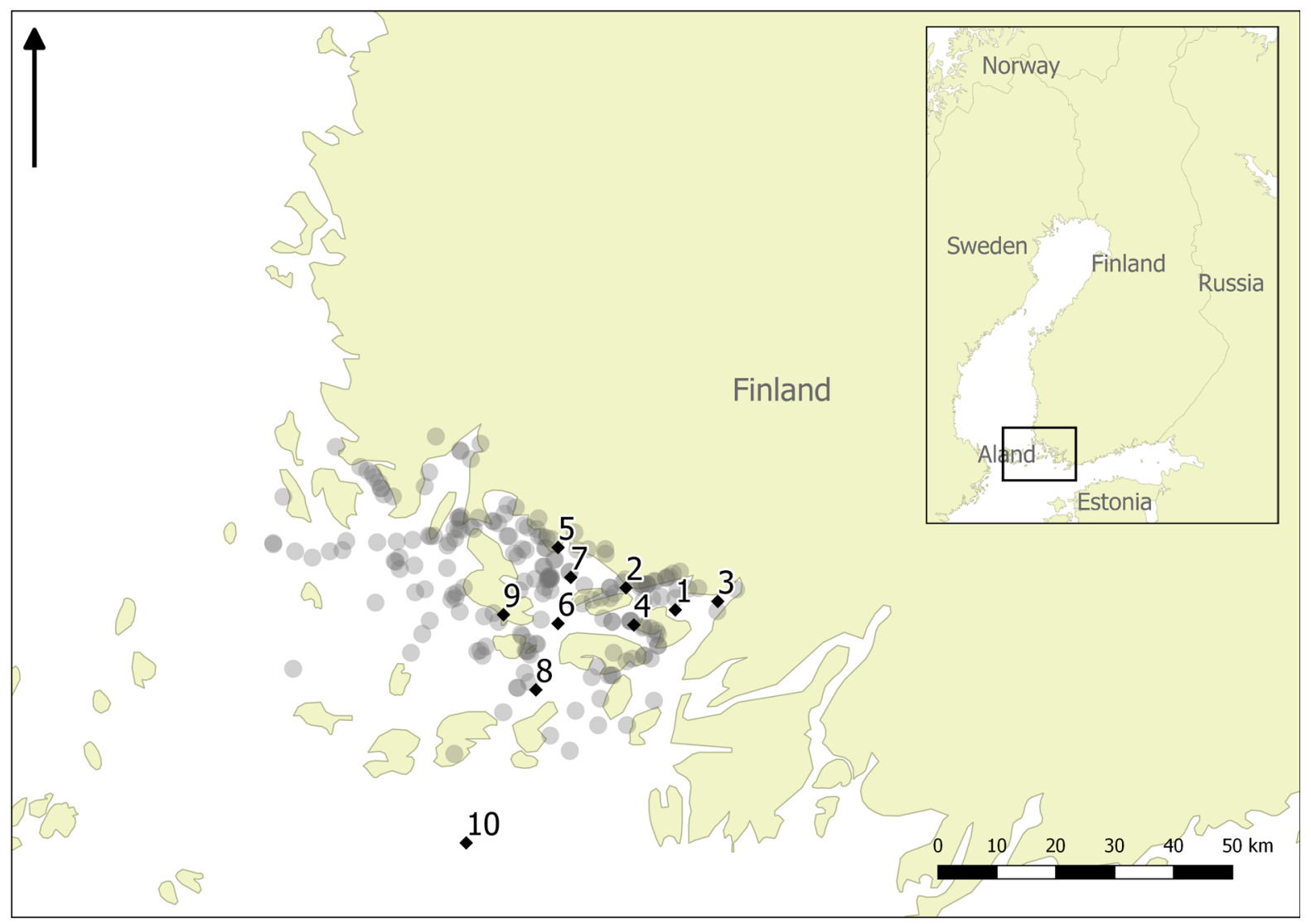

Fig. 1 Map showing the study area overlaid with the range of the $R$. harrisii in Finland in 2013 (grey circles). Exact locations for sampling sites are numbered from 1 to 10 . The southernmost sampling site, Nötö, (10), was excluded from the analyses due to absence of $R$. harrisii in the stomach contents 
Available crabs in the area

Habitat traps were deployed at each site using the methods of Fowler et al. (2013) to assess the size range of $R$. harrisii available in the area at the same time that fish sampling occurred. Traps were deployed for a minimum of 4 days, and all $R$. harrisii retrieved from the traps were measured $(\mathrm{CW}, \mathrm{mm})$, sexed, and counted. The traps do not provide a reliable estimate of absolute $R$. harrisii density, measure per unit of area, but rather provide information on presence/ absence and size distribution. The number of traps as well as the deployment duration varied between the locations. Therefore the data was pooled for further analyses.

\section{Statistical analyses}

Due to the small spatial scale, heterogeneity and unbalanced sampling effort in the area, all data over the sampled area were pooled for the analyses. The proportion and sizes of fish feeding on $R$. harrisii were calculated, and their contribution to total predation on $R$. harrisii was calculated as a percentage. Also, the proportion of stomach contents occupied by $R$. harrisii was calculated for each fish species. Furthermore, the relationship between fish size (TL) and the largest crab consumed (CW) was analyzed using Spearman's correlation coefficient and expressed with a linear equation.

All $R$. harrisii found in fish stomachs and habitat trap samples were classified into size classes in $2 \mathrm{~mm}$ intervals between 1 and $26 \mathrm{~mm}$, reflecting the size range of $R$. harrisii found in the samples. Selectivity by fish predators towards certain crab size classes was calculated using Manly's selectivity index $\alpha$ (Manly 1974)

$$
\alpha_{i}=\frac{\left(\frac{d_{i}}{N_{i}}\right)}{\sum_{i=1}^{k}\left(\frac{d_{i}}{N_{i}}\right)},
$$

where $i$ is the $R$. harrisii size class in question, $k$ is the number of available $R$. harrisii size classes, $d_{i}$ is the proportion that $R$. harrisii size class $i$ is found in a fish stomach and $N_{i}$ is the proportion of $R$. harrisii size class $i$ found in the habitat traps. Manly's $\alpha$ results in values between 0 and 1 , where 0 indicates avoidance (e.g., under-representation of an abundant size class in fish stomachs) and 1 indicates preference (overrepresentation of a size class in fish stomachs). If $\alpha>1 / \mathrm{k}(\mathrm{k}=$ total available size classes), there is predator selection towards that particular size class, and if $\alpha<1 / \mathrm{k}$, there is predator avoidance of that particular size class. If $\alpha=1 / \mathrm{k}$, there is no predator selection, and the different size classes of $R$. harrisii are consumed proportionally to their availability. The number of size classes in the samples was 13 , and therefore the threshold for selection was 0.077 .

The fish consuming $R$. harrisii were divided by their species and size (into 2 size classes, smaller and larger than median TL), and selectivity was calculated for each size class within a fish species.

\section{Results}

Overall, 1286 fish representing 17 species were caught. Intact fish (1185 individuals) were measured and weighed and their stomachs inspected (Table 1). Of these fish, 450 (35\%) had identifiable contents and were included in the detailed stomach content analyses. Remains of $R$. harrisii $(\mathrm{n}=225)$ were found in 100 fish stomachs (7\% of all fish, $22 \%$ of fish with identifiable contents) (Table 2). In some cases $(\mathrm{n}=15)$, the number of $R$. harrisii in a stomach could not be determined and was considered to be one individual to avoid over-estimation.

A total of $678 R$. harrisii were collected from the habitat traps deployed at the fishing sites. The majority of $R$. harrisii ( $\mathrm{n}=389)$ were caught in the western part of the sampling area (inner archipelago) and the least $(\mathrm{n}=46)$ in the southern sites (outer archipelago) (Table 2). Sizes of $R$. harrisii varied between 1.4 and $25.9 \mathrm{~mm}(\overline{\mathrm{X}}=10.83 \mathrm{~mm}$, SD $5.56 \mathrm{~mm})$.

Based on the inspected stomachs, the most $R$. harrisii $(\mathrm{n}=146)$ were eaten by four-horned sculpins (Myoxocephalus quadricornis (Linnaeus, 1758)). Their predation constituted $65 \%$ of all $R$. harrisii found in fish stomachs in this study. Excluding $M$. quadricornis caught from the site which had no $R$. harrisii in the habitat traps (the southernmost location, Nötö), 40 of 48 (83\%) fish had at least one $R$. harrisii present in the stomach contents. The mean size (TL) of M. quadricornis that had consumed crabs was $210 \mathrm{~mm}$ (SD 23; range 180-290 $\mathrm{mm}$ ), and the mean size present in the catch was $217 \mathrm{~mm}$ (SD 34; range 
Table 1 All fish caught that were intact enough to be measured

\begin{tabular}{lrlll}
\hline Species & \# of fish & Mean TL (mm) & Max TL (mm) & Min TL (mm) \\
\hline Perca fluviatilis & 538 & 189 & 310 & 71 \\
Rutilus rutilus & 208 & 232 & 302 & 105 \\
Sander lucioperca & 171 & 250 & 535 & 101 \\
Myoxocephalus quadricornis & 102 & 217 & 298 & 168 \\
Blicca bjoerkna & 50 & 162 & 231 & 100 \\
Abramis brama & 38 & 320 & 480 & 155 \\
Gymnocephalus cernuus & 23 & 137 & 190 & 106 \\
Coregonus lavaretus & 14 & 385 & 450 & 283 \\
Esox lucius & 11 & 624 & 890 & 435 \\
Alburnus alburnus & 8 & 111 & 121 & 102 \\
Platichthys flesus & 6 & 218 & 256 & 191 \\
Clupea harengus membras & 4 & 241 & 275 & 212 \\
Leuciscus ide & 3 & 303 & 388 & 130 \\
Scardinius erythrophthalmus & 3 & 179 & 250 & 165 \\
Osmerus eperlanus & 2 & 176 & 186 & 385 \\
Scopthalmus maximus & 2 & 194 & 202 & \\
Tinca tinca & 2 & 410 & 434 & \\
Total & 1185 & & & \\
\hline & & & & \\
\hline
\end{tabular}

168-298 mm) (Fig. 2a). The average number of $R$. harrisii present in $M$. quadricornis stomachs was 3.7 (SD 2.6), although a maximum of 13 was found in one stomach (TL $229 \mathrm{~mm}$ ). The contribution of $R$. harrisii to the stomach contents of $M$. quadricornis was, on average, $85.3 \%$ when they were present in the stomachs.

Perch (Perca fluviatilis) were the most numerous fish in the catch across all sampling locations. Of 538 perch caught, $41(7.6 \%)$ had at least one $R$. harrisii in the stomach contents. The total number of $R$. harrisii eaten by $P$. fluviatilis was 56. The contribution of $P$. fluviatilis to all $R$. harrisii found in the fish stomachs represented about $26 \%$. The mean size (TL) of $P$. fluviatilis that had eaten $R$. harrisii was $209 \mathrm{~mm}$ (SD 41; range 120-300 $\mathrm{mm}$ ), which was larger than the mean size of $P$. fluviatilis in the catch, $189 \mathrm{~mm}$ (SD 51; range 71-310) (Fig. 2b). P. fluviatilis larger than $200 \mathrm{~mm}$ TL (likely targeted by the recreational and commercial fisheries) consumed $70 \%$ of $R$. harrisii found in all $P$. fluviatilis stomachs. The average number of $R$. harrisii present in $P$. fluviatilis stomachs was 1.5 (SD 0.85), with a maximum of four (TL $225 \mathrm{~mm}$ ). When $R$. harrisii was present in the $P$. fluviatilis stomachs, they accounted for $87.6 \%$ of stomach contents.
A total of 209 roach (Rutilus rutilus (Linnaeus, 1758)) were caught, of which 15 (7.2\%) had eaten $R$. harrisii. Only two $R$. harrisii (both $2 \mathrm{~mm}$ carapace width) were recovered from the stomachs intact enough to be tallied and measured. Therefore, the estimated number of $R$. harrisii eaten by $R$. rutilus was 15 individuals, which contributed about $7 \%$ to all $R$. harrisii found in fish stomachs. The mean size (TL) of $R$. rutilus that had consumed $R$. harrisii was $261 \mathrm{~mm}$ (SD 20; range 228-290 mm). In addition, whole specimens or remains of five $R$. harrisii were found in the stomachs of one ide (Leuciscus ide, (Linnaeus, 1758)), two ruffes (Gymnocephalus cernuus, (Linnaeus, 1758)) and two white breams (Blicca bjoerkna, (Linnaeus, 1758)). Altogether their predation contributed $2 \%$ to the $R$. harrisii found in fish stomachs in this study.

The mean carapace width (CW) of $R$. harrisii eaten by the two most significant predators was approximately $11.6 \pm 2.46 \mathrm{~mm}$ for $P$. fluviatilis and $12.1 \pm 2.54 \mathrm{~mm}$ for M. quadricornis, and majority of $R$. harrisii found from the stomachs were between 9 and $14 \mathrm{~mm} \mathrm{CW}$ (Fig. 3). Based on the habitat trap catch, available $R$. harrisii in the area spanned a much larger size range from 1 to $26 \mathrm{~mm}$ (Fig. 3). Manly's selectivity index showed fish preference towards certain size classes. Small P. fluviatilis (smaller than 


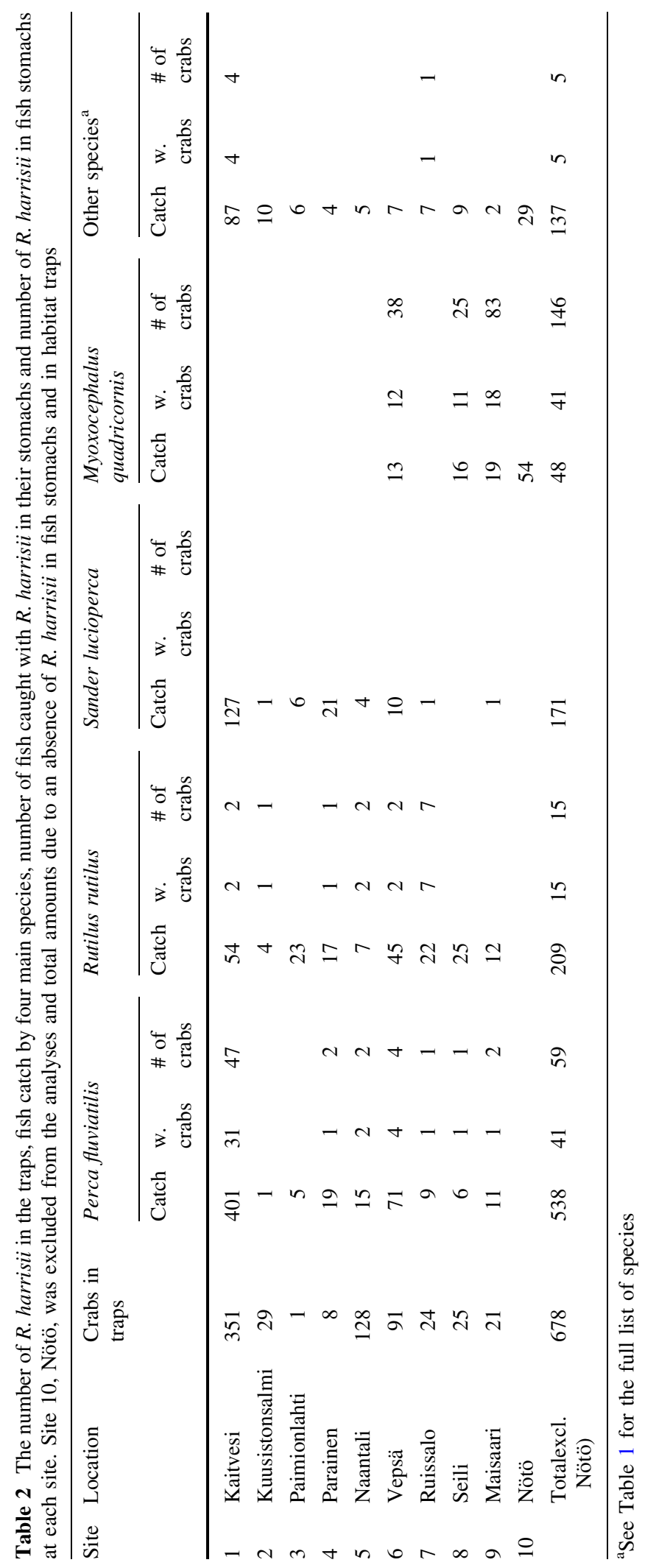


Fig. 2 Number of individual fish in $2 \mathrm{~mm}$ increment size distributions a Perca fluviatilis and b Myoxocephalus quadricornis from the survey (dark grey) and the ones with $R$. harrisii in their stomachs (light grey) (TL: Total length in $\mathrm{mm}$ ) of

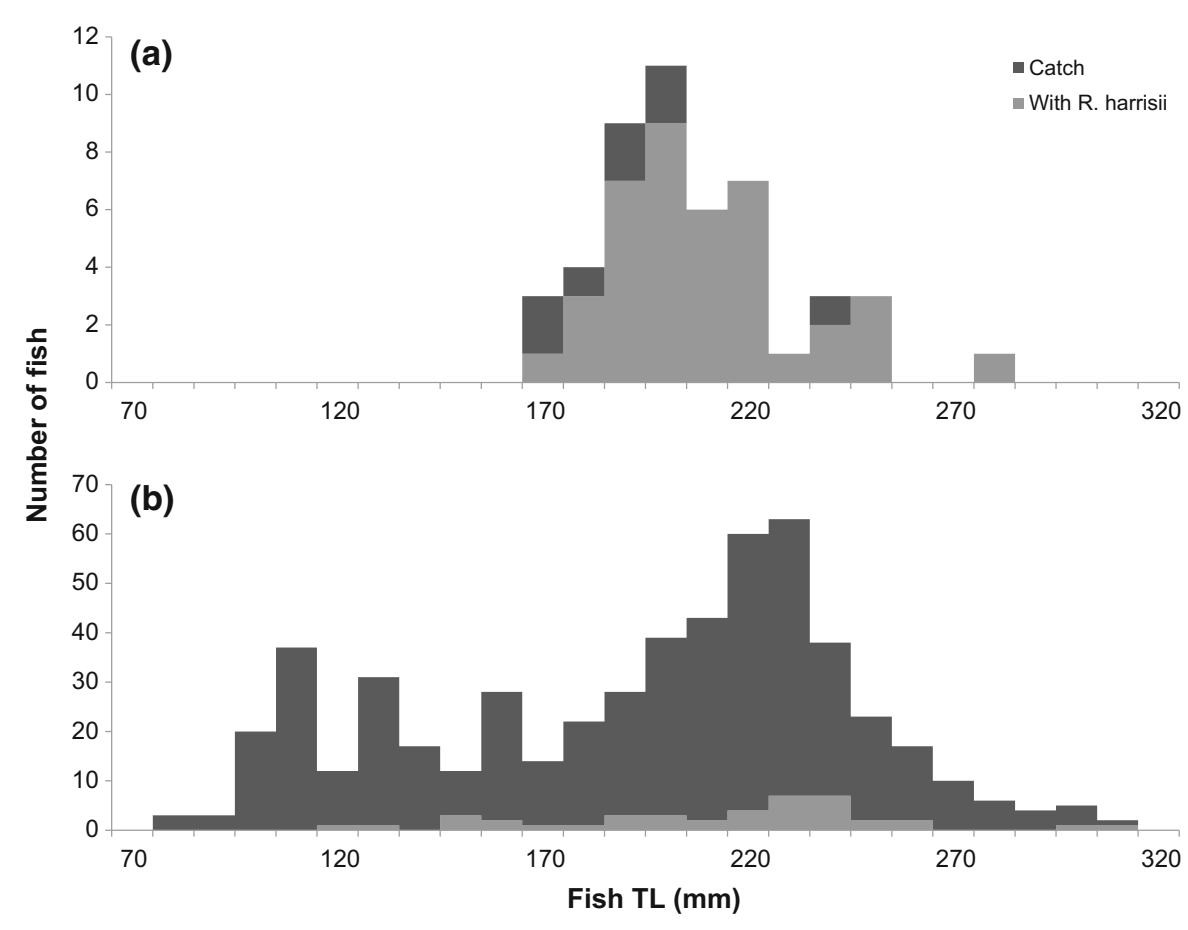

Fig. 3 The proportions of sizes of $R$. harrisii (carapace width in $\mathrm{mm}$ ) available in the area (Available) $(\mathrm{N}=678)$, and the sizes of $R$. harrisii found in the stomachs of Myoxocephalus quadricornis $(\mathrm{N}=146)$ and Perca fluviatilis ( $\mathrm{N}=59)$

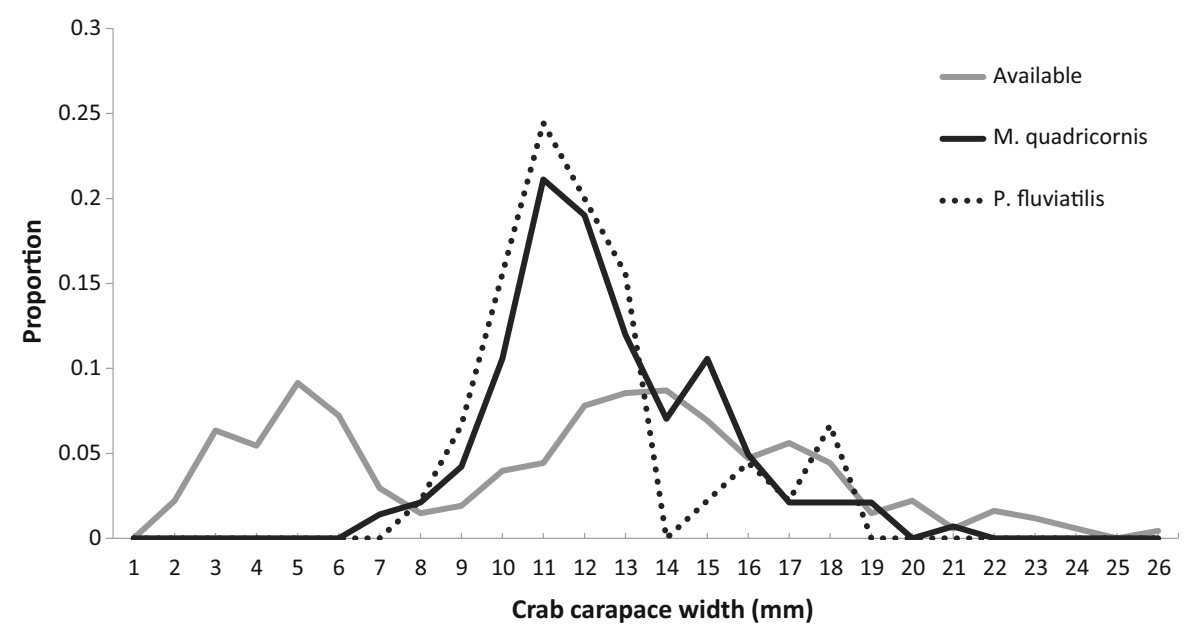

the median TL 222) showed no preference, but larger $P$. fluviatilis preferred $12 \mathrm{~mm} \mathrm{CW} R$. harrisii (Fig. 4a). Small M. quadricornis preferred 12-14 mm CW $R$. harrisii, and larger individuals preferred larger (14-16 mm CW) R. harrisii (Fig. 4b). In both species, larger fish consumed larger $R$. harrisii (P. fluviatilis, $\mathrm{y}=0.0388 \mathrm{x}+5.5976, \mathrm{R}^{2}=0.466$, $\mathrm{p}=0.002 ;$ M. quadricornis, $\mathrm{y}=0.0527 \mathrm{x}+0.5038$, $\left.\mathrm{R}^{2}=0.415, p<0.0001\right)$. Both male and female $R$. harrisii were consumed more or less equally across all fish stomachs (37\% males, $46 \%$ females). The sex could not be determined for approximately $17 \%$ of the crabs (in most cases, juveniles $<4 \mathrm{~mm} \mathrm{CW}$ ).

\section{Discussion}

Some native predators can take advantage of a novel species introducing an alternative food source, and in some cases predators can control the populations of 


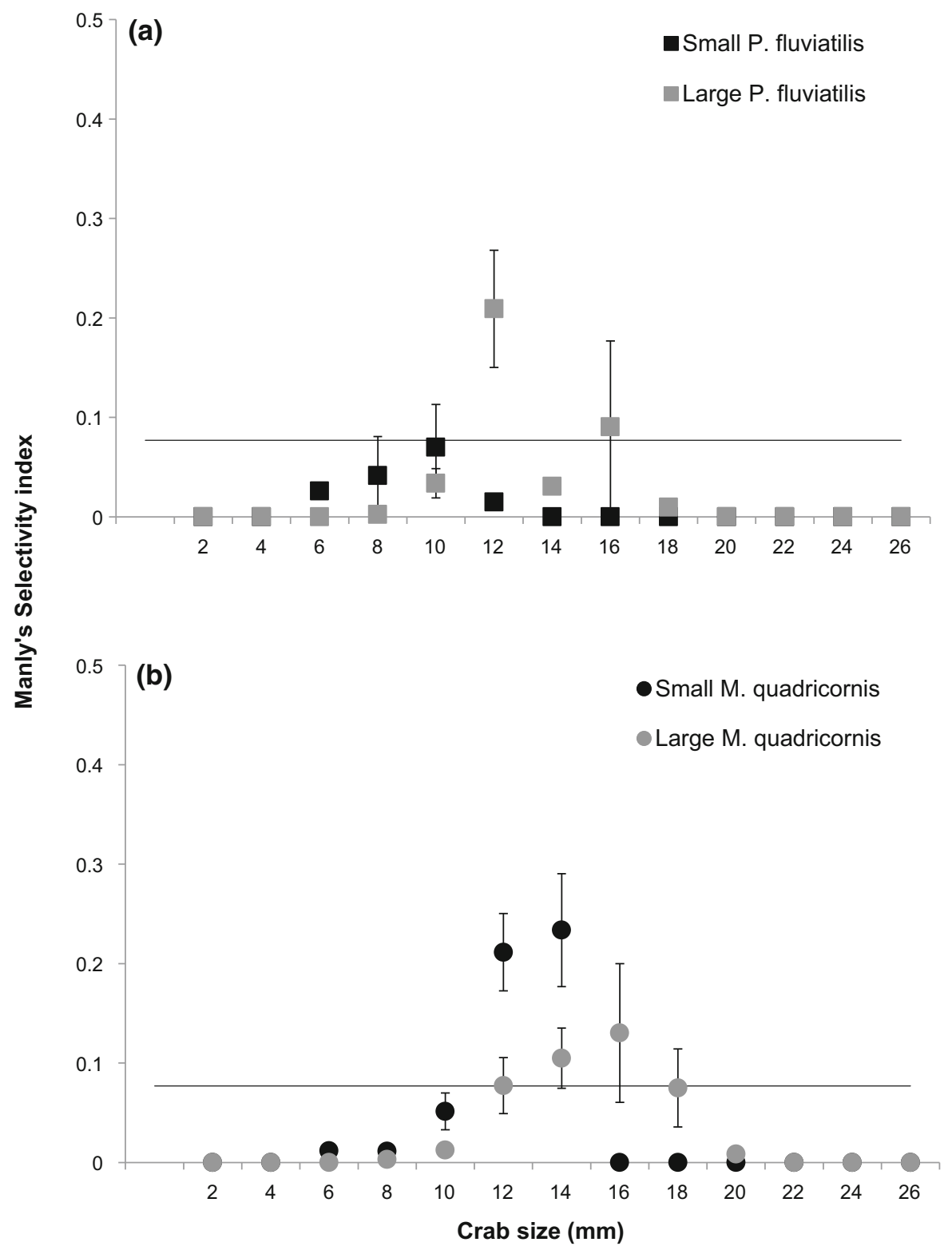

Fig. 4 Manly's selectivity index of two main fish predators towards $R$. harrisii by carapace width ( $\mathrm{mm}$ ) for small and large a Perca fluviatilis and b Myoxocephalus quadricornis. Size classes were determined based on the median total length of fish that had eaten crabs (i.e., $222 \mathrm{~mm}$ for $P$. fluviatilis and $211 \mathrm{~mm}$

these invasive species (Hunt and Yamada 2003; Jensen et al. 2007). Considering the increase in both range and abundance of the introduced Harris mud crab, R. harrisii, in the Archipelago Sea of Finland over the past decade, the fish predation pressure seems inadequate to control their population growth. The results here show that at least a few native fish $(M$. for $M$. quadricornis). The black solid line indicates the threshold value $(1 / \mathrm{k})$ for selection $(0.077)$. Values above the line indicate selection towards the $R$. harrisii carapace size, and values below the line indicate selection against the size. The error bars indicate $1 \mathrm{SE}$

quadricornis, P. fluviatilis, G. cernuus and some cyprinids) consume these novel prey items, although the prevalence of $R$. harrisii in fish stomachs varied greatly among fish species. Furthermore, predation pressure, especially on the larger $R$. harrisii, may be limited by predator size since larger fish tended to target larger crabs. 
Based on the stomach contents of nearly 1200 fish caught in the coastal monitoring effort, M. quadricornis were the main consumers of $R$. harrisii. This may be explained by the fact that sculpins are benthic generalist predators (Savolainen 1975; Timola 1986) and therefore likely to adopt new benthic items into their diet. They are also ambush predators, capable of crushing hard shelled organisms and commonly feed on slow moving invertebrates, such as the benthic isopod Saduria entomon (Leonardsson et al. 1988). Due to their feeding behavior, they would be very likely to encounter $R$. harrisii and feed on them. They also do not seem particularly selective based on previous diet studies (e.g., Savolainen 1975; Timola 1986) and the presence of non-prey items in their stomachs (e.g., small rocks found in this study).

Perca fluviatilis, which have previously been reported to feed on $R$. harrisii in the area (Fowler et al. 2013; FinBIF 2017), consumed fewer $R$. harrisii than M. quadricornis. However, although only about $8 \%$ of $P$. fluviatilis at sites with $R$. harrisii present had consumed them, the overall consumption may be significant due to the high abundance of $P$. fluviatilis in the area, reflected by a recreational catch of 308 tonnes in 2013 (Luonnonvarakeskus 2014). The overall contribution of $P$. fluviatilis to $R$. harrisii predation in this study was about $30 \%$, despite this fish species being the most abundant in the catch. There may be a couple of reasons why $P$. fluviatilis did not consume as many $R$. harrisii as $M$. quadricornis: (1) they are not entirely benthic feeders and would not likely come across $R$. harrisii buried in the substrate and (2) $P$. fluviatilis are visual predators that may not detect $R$. harrisii which are often effectively hiding in structured habitat. In addition, the size range of perch capable of feeding effectively on $R$. harrisii may be limited in the area. Most $R$. harrisii (about 70\%) were consumed by larger P. fluviatilis ( $>200 \mathrm{~mm}$ TL), which is the size at which they begin to be targeted by recreational and commercial fisheries (Setälä et al. 2003), and the catch-per-unit-effort of large (> $250 \mathrm{~mm}$ TL) P. fluviatilis has showed a decline in a part of the study area over the past decade (Heikinheimo et al. 2013). Furthermore, perch tend to switch to fish prey when they grow larger (e.g., Lappalainen et al. 2001).

As prey, R. harrisii offer little, in terms of energetics, to the predator; they have hard shells and relatively small amounts of muscle mass
(Wiszniewska et al. 1998). Slow moving benthic predators, such as $M$. quadricornis, may obtain enough to justify feeding on the crabs, but quickmoving and efficient predators, such as $P$. fluviatilis, can obtain better quality prey and may only occasionally feed on $R$. harrisii that they encounter. This may explain, at least partly, why the prevalence of $R$. harrisii in $M$. quadricornis stomachs was so much higher than in other predatory fish.

Both perch ( $P$. fluviatilis) and four-horned sculpins (M. quadricornis) had consumed mostly 10-12 mm carapace width (CW) $R$. harrisii despite the much broader size range of crabs available in the area. Larger fish, however, showed preference for slightly larger $R$. harrisii (12-16 mm CW). The upper size limit of the preferred prey of each fish species is likely a result of the physical restriction in feeding (gape size) and behavior (larger P. fluviatilis switch to fish prey; Lappalainen et al. 2001). In general, larger fish ate larger crabs likely due to this constraint. However, while larger $R$. harrisii (>18 $\mathrm{mm} \mathrm{CW}$ ) were present in the habitat traps, sometimes in great quantities, they were not found with any frequency in fish stomachs in the study area. Also, P. fluviatilis and M. quadricornis do not grow much larger than the largest fish in our sample (303 and $285 \mathrm{~mm}$ TL, respectively), and large individuals are quite rare in the study area (HELCOM 2006). The largest $R$. harrisii individuals (especially $>19 \mathrm{~mm} \mathrm{CW}$ ), therefore, may benefit from a predation refuge from fish due to their size.

Roach (Rutilus rutilus) and other cyprinid fish may consume more $R$. harrisii than is reflected by our data. The cyprinid feeding structure, i.e., the pharyngeal jaw apparatus (Winfield and Nelson 1991), grinds prey into an unidentifiable state, and therefore $R$. harrisii remains may have gone unnoticed. Based on the $R$. harrisii collected from the fish stomachs, cyprinids preferentially feed on the smallest $R$. harrisii $(2 \mathrm{~mm}$ $\mathrm{CW}$ ), which are abundant in the system. The degree of predation pressure by cyprinids on small $R$. harrisii cannot be estimated from our data, but it could be high due to the large abundance of cyprinids in the area (Heikinheimo et al. 2013; Kääriä et al. 2013; Vielma et al. 2013). Genetic analyses of fish stomach contents could be useful in future evaluation of $R$. harrisii contribution to fish stomach contents for species such as $R$. rutilus.

Although extensive, our sampling data is temporally limited; the survey was conducted in the fall of 
only 1 year. The coastal fish assemblages exhibit seasonal patterns, and some species migrate between deep and shallow waters (Mustamäki et al. 2015). For example, the temperature preference of $M$. quadricornis is around $10{ }^{\circ} \mathrm{C}$, and therefore their range potentially overlaps with $R$. harrisii only when water temperatures are around that preference (e.g., Kottelat and Freyhof 2007). The surface water temperatures were below $12{ }^{\circ} \mathrm{C}$ at the time of sampling, indicating that this study probably accurately reflects or very slightly underestimates the predation of $M$. quadricornis on $R$. harrisii. P. fluviatilis is more abundant in preferred $R$. harrisii habitats, i.e., vegetated shallow areas, year-round, but they feed on $R$. harrisii to a lesser degree. In addition, their tendency to switch to fish prey at larger sizes may further decrease overall predation, especially on large $R$. harrisii. Furthermore, there are probably more fish species present in the area capable of preying on $R$. harrisii, especially other species foraging on the benthos. $R$. harrisii remains have been found in burbot (Lota lota (Oken, 1817)), pikeperch (Sander lucioperca (Linnaeus, 1758)) and whitefish (Coregonus lavaretus (Linnaeus, 1758)) stomachs in the area (Fowler et al. 2013; FinBIF 2017). However, although both $S$. lucioperca and $C$. lavaretus were caught in this study, no $R$. harrisii were detected in their stomachs.

Finally, we know very little about the different foraging strategies and diet switching abilities of many fish species present in the area. Both the diet switching aspect and feeding abilities of predators contribute to how novel prey organisms are adopted into native predator diets and how effective native predators can become in controlling the populations of invasive prey.

Acknowledgements Open access funding provided by Finnish Environment Institute (SYKE). We want to thank Outi Vesakoski from University of Turku for initiating the study. Raisa Kääriä, Jussi Niemi and Jussi Laaksonlaita from Turku University of Applied Sciences were largely responsible for the technical details of the study. Finally, without the help from students Antti Ovaskainen, Eetu Savilahti and Henri Kääriä at Turku University of Applied Sciences, the stomach contents would have never been analyzed. The study was largely funded by the cities of Turku and Kaarina. Riikka Puntila-Dodd's involvement was supported by Maj and Tor Nessling's foundation and the BONUS BIO C3 project, supported by BONUS (Art 185), funded jointly by the EU and the Academy of Finland. Amy Fowler was supported through a Walter and Andree de Nottbeck Foundation Summer Research Fellowship. And last, we are very grateful for the constructive comments we received from the anonymous reviewers during the publication process.

Open Access This article is distributed under the terms of the Creative Commons Attribution 4.0 International License (http:// creativecommons.org/licenses/by/4.0/), which permits unrestricted use, distribution, and reproduction in any medium, provided you give appropriate credit to the original author(s) and the source, provide a link to the Creative Commons license, and indicate if changes were made.

\section{References}

Bacevicius E, Gasiunaite ZR (2008) Two crab species-Chinese mitten crab (Eriocheir sinensis Edw.) and mud crab (Rhithropanopeus harrisii (Gould) ssp. tridentatus (Maitland) in the Lithuanian coastal waters, Baltic Sea. Transit Waters Bull 2:63-68. https://doi.org/10.1285/i1825229Xv2n2p63

Carlton JT, Geller JD (1993) Ecological roulette: the global transport of nonindigenous marine organisms. Science 261:78-82

Crane DP, Farrell JM, Einhouse DW et al (2015) Trends in body condition of native piscivores following invasion of Lakes Erie and Ontario by the round goby. Freshw Biol 60:111-124. https://doi.org/10.1111/fwb.12473

Demel K (1953) Nowy gatunek w faunie Baltyku. Kosmos 2:105-106

DeRivera CE, Ruiz GM, Hines A, Jivoff P (2005) Biotic resistance to invasion: native predator limits abundance and distribution of an introduced crab. Ecology 86:3364-3376

FinBIF (2017) Finnish biodiversity information facility/FinBIF. https://laji.fi/en/taxon/MX.53034. Accessed 21 Jul 2017

Fowler A, Forsström T, von Numers M, Vesakoski O (2013) The North American mud crab Rhithropanopeus harrisii (Gould, 1841) in newly colonized Northern Baltic Sea: distribution and ecology. Aquat Invasions 8:89-96. https:// doi.org/10.3391/ai.2013.8.1.10

Grosholz ED, Ruiz GM (1995) Spread and potential impact of the recently introduced European green crab Carcinus maenas, in central California. Mar Biol 122:239-247

Heikinheimo O, Olsson J, Suleva E (2013) Temporal development of the coastal fish community in Brunskär (Finland), Archipelago Sea. In: HELCOM Balt. Sea Environ. Fact sheets. http://www.helcom.fi/baltic-sea-trends/environ ment-fact-sheets/. Accessed 23 Mar 2016

HELCOM (2006) Assessment of coastal fish in the Baltic Sea. In: Baltic Sea Environment. Proc. No. 103 A, Balt. Sea, p 23

HELCOM (2015) Guidelines for COASTAL FISH monitoring sampling methods of HELCOM. http://www.helcom.fi/ Lists/Publications/Guidelines\%20for\%20Coastal\% 20fish\%20Monitoring\%20of\%20HELCOM.pdf

Hunt CE, Yamada SB (2003) Biotic resistance experienced by an invasive crustacean in a temperate estuary. Biol Invasions 5:33-43

Jensen GC, McDonald PS, Armstrong DA (2007) Biotic resistance to green crab, Carcinus maenas, in California bays. 
Mar Biol 151:2231-2243. https://doi.org/10.1007/s00227007-0658-4

Kääriä R, Heikinheimo O, Olsson J, Suleva E (2013) Temporal development of the coastal fish community in Tvärminne (Finland), western Gulf of Finland Overall state. In: HELCOM Balt. Sea Environ. Fact sheets. http://www. helcom.fi/baltic-sea-trends/environment-fact-sheets/. Accessed 23 Mar 2016

Kotta J, Ojaveer H (2012) Rapid establishment of the alien crab Rhithropanopeus harrisii (Gould) in the Gulf of Riga. Est J Ecol 61:293. https://doi.org/10.3176/eco.2012.4.04

Kottelat M, Freyhof J (2007) Handbook of European freshwater fishes. Cornol \& Freyhof, Berlin

Lappalainen A, Rask M, Koponen H, Vesala S (2001) The diet of perch, Perca fluviatilis L., at Tvärminne, Northern Baltic Sea, and a comparison with two lakes. Boreal Environ Res 10:107-118

Leonardsson K, Bengtsson A, Linnér J (1988) Size-selective predation by fourhorn sculpin, Myoxocephalus quadricornis (L.) (Pisces) on Mesisotea entomon (L.) (Crustacea, Isopoda). Hydrobiologia 164:213-220

Luonnonvarakeskus (2014) Vapaa-ajankalastus 2012. In: Kalaja riistatilastot. http://stat.luke.fi/vapaa-ajankalastus. Accessed 3 Sep 2015

Manly B (1974) A model for certain types of selection experiments. Biometrics 30:281-294

Mustamäki N, Jokinen H, Scheinin M et al (2015) Seasonal small-scale variation in distribution among depth zones in a coastal Baltic Sea fish assemblage. Ices J Mar Sci. https:// doi.org/10.1093/icesjms/fsv068

Noonburg EG, Byers JE (2005) More harm than good: when invader vulnerability to predators enhances impact on native species. Ecology 86:2555-2560. https://doi.org/10. 1890/05-0143

Odum WE, Heald EJ (1972) Trophic analyses of an estuarine mangrove community. Bull Mar Sci 22:671-738

Ojaveer H, Gollasch S, Jaanus A et al (2006) Chinese mitten crab Eriocheir sinensis in the Baltic Sea-a supply-side invader? Biol Invasions 9:409-418. https://doi.org/10. 1007/s10530-006-9047-z

RKTL (2013) Commercial marine fishery 2012 Riista-ja kalatalous-Tilastoja 3/2013. Official Statistics of FinlandAgriculture, Forestry and Fishery, Helsinki, Finland

Roche DG, Torchin ME (2007) Established population of the North American Harris mud crab, Rhithropanopeus harrisii (Gould, 1841) (Crustacea: Brachyura: Xanthidae) in the Panama Canal. Aquat Invasions 2:155-161. https:// doi.org/10.3391/ai.2007.2.3.1

Savolainen E (1975) Distribution and food of Myoxocephalus quadricornis (L.) (Teleostei, Cottidae) in fresh waters of eastern Finland. Ann Zool Fennici 12:271-274

Schubert K (1936) Pilumnopeus tridentatus Maitland, eine neue Rundkrabbe in Deutschland. Zool Anz 116:320-323

Setälä J, Heikinheimo O, Saarni K, Raitaniemi J (2003) Verkon solmuvälin suurentamisen vaikutus Saaristomeren ammattikalastuksen kuha-ja ahvensaaliin arvoon. Kala-ja riistaraportteja 297:36 + 4

Sih A, Bolnick DI, Luttbeg B et al (2010) Predator-prey naiivete, antipredator behavior, and the ecology of predator invasions. Oikos 119:610-621. https://doi.org/10.1111/j. 1600-0706.2009.18039.x

Simberloff D, Martin JL, Genovesi P et al (2013) Impacts of biological invasions: what's what and the way forward. Trends Ecol Evol 28:58-66. https://doi.org/10.1016/j.tree. 2012.07.013

Timola O (1986) Diet of the fourhorn sculpin, Myoxocephalus quadricornis, among the innermost islands and in the open sea in the NE Bothnian Bay. Bothnian Bay Rep 4:3-13

Vielma J, Setälä J, Airaksinen S, et al (2013) Vähäarvoisen kalamateriaalin jalostus lisäarvotuotteiksi-liiketoimintanäkymät. RKTL:n työraportteja 28/2013

Ward A, Reid A, Seebacher F (2010) Learning to hunt: the role of experience in predator success. Behaviour 147:223-233. https://doi.org/10.1163/000579509X12512871386137

Williams AB (1984) Shrimps, lobsters, and crabs of the Atlantic coast of the eastern United States, Maine to Florida. Smithsonian Institution Press, Washington, DC

Winfield I, Nelson JS (eds) (1991) Cyprinid fishes: systematics, biology and exploitation. Springer, Berlin

Wiszniewska A, Rychter A, Szaniawska A (1998) Energy value of the mud crab Rhithropanopeus harrisii ssp. tridentatus (Crustacea, Decapoda) in relation to season, sex and size. Oceanologia 40:231-241

Publisher's Note Springer Nature remains neutral with regard to jurisdictional claims in published maps and institutional affiliations. 